\title{
In vitro ruminal fermentation characteristics and utilisable CP supply of sainfoin and birdsfoot trefoil silages and their mixtures with other legumes
}

\author{
A. Grosse Brinkhaus ${ }^{1,2}$, U. Wyss ${ }^{1}$, Y. Arrigo ${ }^{1}$, M. Girard ${ }^{1,2}$, G. Bee $^{1}$, J. O. Zeitz ${ }^{2 a}$, M. Kreuzer ${ }^{2}$ \\ and F. Dohme-Meier ${ }^{1 t^{\prime}}$
}

${ }^{1}$ Agroscope, Institute for Livestock Sciences (ILS), Tioleyre 4, 1725 Posieux, Switzerland; ${ }^{2}$ Institute of Agricultural Sciences, ETH Zurich, Universitätstrasse 2, 8092 Zurich, Switzerland

(Received 8 December 2015; Accepted 22 July 2016; First published online 31 August 2016)

\begin{abstract}
The extensive protein degradation occurring during ensiling decreases the nutritive value of silages, but this might be counteracted by tannins. Therefore, silages from two legume species containing condensed tannins (CT) - sainfoin (SF) and birdsfoot trefoil (two cultivars: birdsfoot trefoil, cv. Bull (BTB) and birdsfoot trefoil, cv. Polom) - were compared for their in vitro ruminal fermentation characteristics. The effect of combining them with two CT-free legume silages (lucerne $(L U)$ and red clover $(R C)$ ) was also determined. The supply of duodenally utilisable $C P(u C P)$ in the forages was emphasised. The legumes were each harvested from three field sites. After $24 \mathrm{~h}$ of wilting on the field, the legumes were ensiled in laboratory silos for 86 days. Proximate constituents, silage fermentation characteristics, CT content and CP fractions were determined. Subsequently, silage samples and 1:1 mixtures of the CT-containing and CT-free silages were incubated for $24 \mathrm{~h}$ in batch cultures using ruminal fluid and buffer $(1: 2, \mathrm{v} / \mathrm{v})$. Each treatment was replicated six times in six runs. The effects on $\mathrm{pH}$, ammonia and volatile fatty acid concentrations, protozoal counts, and total gas and methane production were determined. $\mathrm{C} C \mathrm{P}$ content was calculated by considering the $\mathrm{CP}$ in the silage and the ammonia in the incubation fluid from treatments and blanks. Statistical evaluation compared data from single plants alone and together with that from the mixtures. Among treatments, SF silage contained the least CP and the most CT. The non-protein nitrogen content was lower, favouring neutral detergent soluble and insoluble protein fractions, in the SF and $R C$ silages. Absolute UCP content was lowest in SF and SF mixtures, although the ratio to total CP was the highest. In comparison with LU, the ammonia concentration of the incubation fluid was lower for SF, RC and BTB and for the mixture of SF with LU. The total gas and methane production was similar among the treatments, and the total volatile fatty acid production was decreased with the CT-containing legumes. Protozoal count was increased with the mixtures containing LU and either SF or BTB compared with single $L U$. In conclusion, compared with the other legumes, SF and RC have similar advantages as they show limited proteolysis during ensiling. In addition, SF supplies more UCP relative to total CP. The CT-containing legumes also differed in their effect on ruminal fermentation and ammonia formation, probably because of their different CT contents. Thus, SF and its mixtures appear promising for improving the protein utilisation of ruminants.
\end{abstract}

Keywords: condensed tannin, legume silage, ruminal fermentation, utilisable CP

\section{Implications}

Silage has become an important forage type in ruminant nutrition, but proteolysis during ensiling increases the amounts of fast and easily degradable nitrogen (N)-containing compounds in the rumen. This could enhance protein loss, leading to a metabolic and environmental $\mathrm{N}$

aresent address: Institute of Animal Nutrition and Nutritional Physiology, Justus-Liebig-University Giessen, Heinrich-Buff-Ring 26-32, 35392 Giessen, Germany.

${ }^{\dagger}$ E-mail: frigga.dohme-meier@agroscope.admin.ch load. This in vitro study revealed that condensed tannins (CT) present in some legume silages may reduce proteolysis during ensiling, thereby lowering the metabolic and environmental load and supplying more utilisable $\mathrm{CP}(\mathrm{uCP})$ at the duodenum.

\section{Introduction}

Many European ruminant production systems conserve an increasing proportion of forage as silage because this conservation technique is less weather dependent than 
haymaking and easily feasible due to modern production technology (Wilkinson and Toivonen, 2003). However, the quality of silage from the same original harvested material can vary widely due to plant respiration, plant enzyme activity, clostridial activity or aerobic microbial activity (Muck, 1988). Protease activity is particularly detrimental as it promotes the formation of soluble $\mathrm{N}$ compounds, which could lead to high ammonia $\left(\mathrm{NH}_{3}\right)$ concentrations in ruminants when they are fed (Charmley, 2001). Detoxification of excessive ruminal $\mathrm{NH}_{3}$ by ureagenesis is also energy consuming and increases the metabolic load. According to Lobley et al. (1995) ureagenesis has been estimated to contribute $13 \%$ to $16 \%$ to liver energetics in cattle. Wilting of the plant before ensiling can reduce proteolytic processes (Edmunds et al., 2014), but the choice of plant may also be important in this respect.

Among legumes, lucerne (LU) is a species that is easily established in dry growing conditions and is characterised by a high yield, whereas red clover (RC) is particularly well adapted for growing conditions with greater humidity (Sheldrick et al., 1995). Both of these legumes are rich in CP, but the ruminal degradation rate of the legume $C P$ is generally high. Furthermore, the level of LU CP that is utilisable at the duodenum (uCP; basically metabolisable protein) is further reduced by ensiling (Lüscher et al., 2014). This situation might be different in legumes that contain bioactive compounds like $\mathrm{CT}$, which are becoming more important in ruminant nutrition (Waghorn, 2008).

At pH 3.5 to 7, CT form complexes with proteins (MuellerHarvey, 2006) and carbohydrates (McSweeney et al., 2001). These complexes may cause a reduced ruminal degradation rate of nutrients, thereby preventing $\mathrm{NH}_{3}$ formation and reducing urinary $\mathrm{N}$ loss (Mueller-Harvey, 2006), as well as preserving dietary $\mathrm{CP}$ as $\mathrm{UCP}$. In addition, $\mathrm{CT}$ bind to the cell coat polymers of some bacteria and can decrease their enzyme activity (Jones et al., 1994). Complexes with carbohydrates that result in lower concentrations of $\mathrm{H}_{2}$, as well as decreased enzyme activity, might also decrease methane $\left(\mathrm{CH}_{4}\right)$ production (Patra and Saxena, 2011). Another possibility is that CT-containing forages can improve silage quality directly, by decreasing the proteolysis that occurs during ensiling. This is indicated by the lower content of soluble $\mathrm{N}$ compounds identified in these silages (Copani et al., 2014). Consequently, CT might increase the content of UCP during both the ensiling and ruminal nutrient degradation processes.

A severe disadvantage of the CT-containing legumes growing in temperate climates is their low yield. Therefore, mixtures of high-yield non-CT-containing and medium-yield CT-containing legumes would be particularly attractive as forages. However, it remains unclear whether the positive properties of both types of legumes are conserved, or whether they act synergistically (i.e. the presence of the CT restricts the degradation of the protein from the legumes), antagonistically (i.e. the CT content is too low to be effective) or additively (i.e. the presence of $\mathrm{CT}$ restricts the degradation of the protein, but the effect is lower compared with that of the single (T-containing legumes). The lower ruminal $\mathrm{NH}_{3}$ concentrations observed when feeding mixtures of $L U$ and sainfoin (SF) (Wang et al., 2006) or birdsfoot trefoil (BT) (Williams et al., 2010), compared with single LU, suggest a synergistic effect. Nevertheless, to our knowledge, the impact of mixing non-CT-containing and CT-containing legumes on the uCP content has not yet been tested.

Therefore, in the present study, three hypotheses were tested. (i) The silage quality of CT-containing legumes is comparable with that of common non-CT-containing forage legumes. (ii) The CT-containing legumes change ruminal fermentation in a way which increases the amount of $\mathrm{uCP}$. (iii) Mixtures of non-CT-containing legumes with CT-containing legumes act synergistically in this respect. In order to have a wide coverage for testing these hypotheses, two CT-containing species (SF and BT, the latter represented by two cultivars) and two non-CT-containing species (LU and RC) were included in the experiment. Silages of single legumes were prepared at laboratory scale, and ruminal fermentation was simulated in batch cultures using single legumes and 1:1 mixtures of CT-containing and non-CT-containing legumes.

\section{Material and methods}

\section{Silage preparation}

LU (Medicago sativa, cv. Sanditi), RC (Trifolium pratense, cv. Milvus), SF (Onobrychis viciifolia, Cv. Perly) and two BT cultivars (Lotus corniculatus, cv. Bull (BTB) and cv. Polom (BTP)) were sown in April 2012 in Posieux, Switzerland (latitude: $46^{\circ}$ $46^{\prime} \mathrm{N}$, longitude: $07^{\circ} 06^{\prime} \mathrm{E}$, altitude: $650 \mathrm{~m}$ ) in a field of 0.7 ha each. Each field was divided into three plots, and sampling from the plots was done at distances of $\sim 150 \mathrm{~m}$ from the next sampling site, in order to obtain three independent batches (replicates) per legume. The sowing density was $26 \mathrm{~kg} / \mathrm{ha}$ for LU, $23 \mathrm{~kg} / \mathrm{ha}$ for RC, $160 \mathrm{~kg} / \mathrm{ha}$ for SF and $30 \mathrm{~kg} / \mathrm{ha}$ for BTB and BTP each. The germination rate for each legume was as follows: $\leqslant 82 \%$ for $\mathrm{LU}, \leqslant 85 \%$ for $\mathrm{RC}, \leqslant 85 \%$ for SF, $\leqslant 75 \%$ for BTB and $\leqslant 75 \%$ for BTP. All legumes were cut at $1300 \mathrm{~h}$ at $6 \mathrm{~cm}$ above ground on day 73 after seeding. At that time, the SF was at the full flowering stage, whereas LU, RC, BTB and BTP were at the early flowering stage. The weed proportions in the swards were $10 \%, 14 \%, 8 \%, 49 \%$ and $49 \%$ of harvested biomass for LU, RC, SF, BTB and BTP, respectively. Weeds included Plantago media and Stellaria media. Sward samples were taken from each legume directly after cutting and after $24 \mathrm{~h}$ of wilting. The wilted samples were chopped into 1 to $2 \mathrm{~cm}$ pieces with a chaff cutter (Mex GT; Poettinger, Grieskirchen, Austria) and ensiled without additives in silo containers (one $0.5 \mathrm{I}$, three $1.5 \mathrm{I}$ and one $30 \mathrm{I}$ container/batch and per legume). The silos were covered airtight and stored in a dark room at room temperature. The dry matter (DM) losses were determined by weighing the $1.5 \mathrm{I}$ silos every week on a scale (ID1; Mettler Toledo, Greifensee, Switzerland) and additionally corrected for losses due to evaporation of volatile compounds and respiratory processes according to Weissbach and Kuhla (1995). On day 3, the $0.5 \mathrm{I}$ silos were opened for $\mathrm{pH}$ determinations. 
After 86 days, the remaining silos were opened. Silage material from the $1.5 \mathrm{I}$ silos was pooled by batch, and two subsamples were taken to determine silage characteristics and protein fractions. The silage material contained in the 30 I silos was subdivided: one part was vacuum packaged and stored at $-20^{\circ} \mathrm{C}$ until used for the in vitro incubation. The remaining part, the fresh and wilted material collected before ensiling and one subsample from the $1.5 \mathrm{I}$ silos were lyophilised (Christ, Osterode, Germany) for later analysis of the chemical composition.

\section{Laboratory analysis of the silages}

Silage $\mathrm{pH}$ was determined by inserting an electrode (No. 6.0202.110; Metrohm Schweiz AG, Zofingen, Switzerland) connected to an ion metre (pH/ionmeter 692; Metrohm Schweiz AG) into the filtered fluid extracted from $40 \mathrm{~g}$ samples shaken for $30 \mathrm{~min}$ with $400 \mathrm{ml}$ of distilled water. The $\mathrm{NH}_{3}$ content of each extract was also determined with an $\mathrm{NH}_{3}$ electrode (No. 6.0506.010; Metrohm Schweiz AG).

Solutions of $\sim 10 \mathrm{~g}$ silage, $90 \mathrm{ml}$ distilled water, $2.5 \mathrm{ml}$ Carrez I $\left(18 \mathrm{~g} \mathrm{~K}_{4} \mathrm{Fe}(\mathrm{CN})_{6} \times 3 \cdot \mathrm{H}_{2} \mathrm{O}\right.$ in $500 \mathrm{ml}$ distilled water) and $2.5 \mathrm{ml}$ Carrez II $\left(36 \mathrm{~g} \mathrm{ZnSO}{ }_{4} \times 7 \cdot \mathrm{H}_{2} \mathrm{O}\right.$ in $500 \mathrm{ml}$ distilled water) were shaken and extracted for $3 \mathrm{~h}$ to determine the volatile fatty acids (VFA) and short-chain alcohol contents. The acetate, propionate, butyrate, iso-butyrate, valerate, iso-valerate, lactate, propanol, propanediol, butanediol, butanol and ethanol contents of the extracts were analysed by HPLC (Summit1; Dionex, Dublin, Ireland) equipped with a nucleogel ION 300 OA $300 \times 7.8 \mathrm{~mm}$ column (MachereyNagel GmbH, Düren, Germany) and a Shodex Rl-101 refractive index detector (Shodex, Munich, Germany).

The lyophilised samples were milled to pass a $1.0 \mathrm{~mm}$ sieve (Brabender mill; Brabender, Duisburg, Germany). The DM was quantified gravimetrically by heating for $15 \mathrm{~h}$ at $60^{\circ} \mathrm{C}$ followed by $3 \mathrm{~h}$ at $105^{\circ} \mathrm{C}$. The DM values were corrected for losses due to the evaporation of volatile compounds and respiratory processes according to Weissbach and Kuhla (1995). Organic matter (OM) was calculated from the amount of DM and total ash, which was determined by dry-ashing for $4 \mathrm{~h}$ at $550^{\circ} \mathrm{C}$ (Association of Official Analytic Chemists (AOAC), 1995; procedure no. 942.05). An ANKOM 200/220 Fiber Analyzer (ANKOM Technology Cooperation, Fairport, NY, USA) was used for NDF and ADF analysis according to standard protocols (AOAC, 1995; procedure no. 973.18 for ADF and procedure no. 2002.04 for NDF) where NDF was analysed with heat stable amylase and sodium sulphite. Both NDF and ADF were expressed without residual ash (determined by $1 \mathrm{~h}$ of incineration). Total $\mathrm{N}$ was analysed using the Kjeldahl method (AOAC, 1995; procedure no. 988.05), and CP was calculated as $6.25 \times \mathrm{N}$.

The total, soluble, protein-bound and fibre-bound CT contained in the SF, BTB and BTP silages were analysed using the $\mathrm{HCl}$-butanol method described by Terrill et al. (1992). In brief, for the first extraction to determine the soluble $\mathrm{CT}$, $\sim 0.5 \mathrm{~g}$ ground plant material DM was mixed with an acetone : water solution $(7: 3, \mathrm{v} / \mathrm{v})$ containing ascorbic acid ( $1 \mathrm{~g} / \mathrm{l})$ and diethyl ether. After mixing and centrifugation, the aqueous phase was collected and concentrated. The solid residue containing the insoluble $\mathrm{CT}$ fraction was treated with a mix of SDS and 2-mercaptoethanol, heated for $45 \mathrm{~min}$ at $95^{\circ} \mathrm{C}$ and then centrifuged for $15 \mathrm{~min}$ at $25000 \times \mathrm{g}$. After centrifugation, the supernatant was used to determine the amount of protein-bound $\mathrm{CT}$, and the solid residue was kept to determine the amount of fibre-bound CT. The soluble and protein-bound fractions were heated with a $\mathrm{HCl}$-butanol solution $(5: 95, v / v)$. The fibre-bound fraction was heated with a HCl-butanol solution $(5: 95, \mathrm{v} / \mathrm{v})$ and SDS-2mercaptoethanol. After colour development, its intensity was measured with an absorbance spectrometer (Lamda 40; Perkin Elmer Instruments, Waltham, MA, USA) at $550 \mathrm{~nm}$. Standards for concentration of CT were prepared from fresh samples of SF, BTP and BTB by extraction of the CT with an acetone: water solution $(7: 3, \mathrm{v} / \mathrm{v})$ containing ascorbic acid $(1 \mathrm{~g} / \mathrm{l})$, followed by purification on a Sephadex LH-20 column (Sigma Aldrich, St. Louis, MO, USA). With these extracts, calibration curves were determined. Total phenolic compounds were analysed according to Salminen and Karonen (2011) and were expressed as gallic acid equivalents. The amounts of non-protein $N(A)$, true soluble protein $\left(B_{1}\right)$, neutral detergent soluble protein $\left(B_{2}\right)$, protein insoluble in neutral detergent but soluble in acid detergent $\left(B_{3}\right)$ and protein insoluble in acid detergent $(C)$ were determined using a modified Kjeldahl method, as described by Licitra et al. (1996).

\section{In vitro incubation}

The Hohenheim Gas Test, developed by Menke and Steingass (1988), was used as an in vitro batch culture system. An amount of fresh silage material (single or 1:1 mixtures) equivalent to $200 \mathrm{mg}$ DM of the CT-containing legumes (SF, BTB, BTP) and either LU or RC were incubated separately for each batch in six runs performed on different days. Due to liquid leakage and oxygen entry, the incubation failed for some pistons, which ultimately resulted in an average of five repetitions per batch. Before incubation, the samples were ground to $\sim 5 \mathrm{~mm}$ using a Moulinex food processor (Moulinex, Glattpark, Switzerland).

Ruminal fluid was collected before morning feeding from a ruminally cannulated Brown Swiss cow receiving grass hay for ad libitum intake. The cow was housed and cared for according to the Swiss legislation for animal welfare (https:// www.admin.ch/opc/de/classified-compilation/20080796/ index.html). The ruminal fluid was filtered through four layers of gauze and directly mixed with a preheated buffer solution (1:2, v/v; Menke and Steingass, 1988), which was flushed with $\mathrm{CO}_{2}$ before use. Each modified piston (Soliva and Hess, 2007) was filled with $30 \mathrm{ml}$ of the incubation fluid, closed airtight and incubated for $24 \mathrm{~h}$ at $39^{\circ} \mathrm{C}$ in an incubator with a slow rotation. After $8 \mathrm{~h}$ of incubation, the gas volume was read from the calibrated scale printed onto the piston. When it exceeded $50 \mathrm{ml}$, a $0.150 \mathrm{ml}$ sample was removed through an airtight septum with a sampling injector syringe (Hamilton Company, Reno, NV, USA), and the residual gas was released directly afterwards. 
As $\mathrm{CH}_{4}$ was not produced linearly during the incubation period, its concentration was directly measured in the gas from the syringes using a gas chromatograph (5890, series II; Hewlett Packard, Avondale, PA, USA) equipped with a $2.34 \mathrm{~m} \times 2.3 \mathrm{~mm}$ column (mesh size 60/80; Fluka Chemie AG, Buchs, Switzerland) and a flame ionisation detector. After $24 \mathrm{~h}$, the incubation was stopped by removing the pistons from the incubator and the gas volume was recorded. The corrected total gas production was calculated as described by Menke and Steingass (1988) after taking gas produced by blanks and standard samples into account. Total $\mathrm{CH}_{4}$ production was calculated with the gas volume and concentrations measured at 8 and $24 \mathrm{~h}$ of incubation. It was corrected by the blank samples where the same procedure was applied.

The fluid and the incubation residue were released through the outlet of the piston, and a $10 \mathrm{ml}$ volume of the fluid was collected, mixed with $0.2 \mathrm{ml}$ of $50 \% \mathrm{H}_{2} \mathrm{SO}_{4}$ and immediately frozen at $-20^{\circ} \mathrm{C}$ for later analysis of total and individual VFA, as described for the silage samples. In addition, $500 \mu \mathrm{l}$ of the incubation fluid was mixed with $500 \mu \mathrm{l}$ of $6 \%$ formalin for microscopy determination of the total counts of Holotrich and Entodiniomorph protozoa cells using a Bürker counting chamber ( $0.1 \mathrm{~mm}$ depth; Brand $\mathrm{GmbH} \& \mathrm{Co}$. $K G$, Wertheim, Germany). The remaining fluid and the residue were centrifuged together at $20000 \times \mathbf{g}$ for $30 \mathrm{~min}$ at $4^{\circ} \mathrm{C}$. The resulting supernatant was used for $\mathrm{pH}$ and $\mathrm{NH}_{3}$ determination with the appropriate electrodes $\mathrm{(pH}, \mathrm{HI} 223$; Hanna Instruments Switzerland AG, Sursee, Switzerland; for $\mathrm{NH}_{3}$, No. 6.0506.100, Metrohm Schweiz AG). The $\mathrm{NH}_{3}$ electrode was connected to a potentiometer (model 632; Metrohm Schweiz AG).

\section{Calculations and statistical analysis}

The uCP content of the single silages and mixtures was calculated as described by Steingass and Südekum (2013) using the following formula:

$$
\mathrm{uCP}=[(\mathrm{NB}+\mathrm{NL}-\mathrm{NI}) \times 6.25] /(\mathrm{IW} \times \mathrm{DM})
$$

where NB is the average $\mathrm{NH}_{3}-\mathrm{N}$ concentration of the blanks, $\mathrm{NL}$ the $\mathrm{N}$ content of the silage sample, $\mathrm{NI}$ the $\mathrm{NH}_{3}-\mathrm{N}$ concentration of the incubation fluid after $24 \mathrm{~h}$ and IW the initial weight of the incubated silage sample. The values of the silage quality and chemical composition were averaged over the three batches per legume, and the means are displayed in the tables. The protein fraction data were subjected to ANOVA using the MIXED procedure of the SAS 9.2 software with treatment as fixed effects. Multiple comparisons among means were calculated using Tukey's procedure.

Explorative graphics and residual analyses of parametric models led to the decision to apply non-parametric inferential methods for the data obtained from the in vitro incubation. The focus of the study was on the treatment comparisons of the single legumes and the mixtures and on the comparison of the single legumes with the respective mixtures; therefore, rank-based ANOVA (KruskalWallis tests) and pairwise comparisons of treatments
(Wilcoxon-Mann-Whitney tests) were applied at the significance level of $P<0.05$ using the statistical package of the $R$ 3.1.2 program ( $R$ Core Team, 2014). The different batches were treated as replicates for the respective legumes. This resulted, on average, in 15 incubations/legume $(n=15)$. The means were trimmed at $10 \%$, and the pooled standard errors of the means are displayed in the tables.

\section{Results}

\section{Silage characteristics}

The $\mathrm{pH}$ of all silages declined between the $3^{\text {rd }}$ and $86^{\text {th }}$ days to a $\mathrm{pH}<5$ (Table 1). After 86 days, the $\mathrm{pH}$ was lowest in the RC and SF silages, followed by the BTP, BTB and LU silages. Total DM losses were all $<50 \mathrm{~g} / \mathrm{kg}$ and were lowest for the LU silage, followed by the SF, BTB, BTP and RC silages. The DM content was lowest in the RC silage, followed by the BTP, BTB and SF silages, and was highest in the $\mathrm{LU}$ silage. The $\mathrm{NH}_{3}$ concentration was lowest in the SF silage, followed by the RC, LU, BTP and BTB silages. The lowest concentration of ethanol was found in the RC and LU silages, followed by the BTP, BTB and SF silages. The concentrations of acetate and lactate were lowest for the SF and LU silages, followed by the BTP and BTB silages, and were highest for the RC silage. The other organic acids (propionate, butyrate, iso-butyrate, valerate and iso-valerate) and alcohols (propanol,

Table 1 Characteristics of the legume silages after 86 days of ensiling $(\mathrm{n}=3)$

\begin{tabular}{|c|c|c|c|c|c|}
\hline \multirow[b]{2}{*}{ Items } & \multicolumn{5}{|c|}{ Legumes } \\
\hline & LU & $\mathrm{RC}$ & SF & BTB & BTP \\
\hline \multicolumn{6}{|c|}{ Fermentation variables ${ }^{1}$} \\
\hline $\mathrm{pH}_{3 \text { days }}^{2}$ & 5.90 & 5.01 & 5.46 & 5.22 & 5.19 \\
\hline $\mathrm{pH}_{86 \text { days }}$ & 4.84 & 4.40 & 4.43 & 4.62 & 4.57 \\
\hline DM losses (g/kg) & 37.1 & 47.6 & 41.2 & 42.6 & 42.8 \\
\hline $\mathrm{NH}_{3}$ & 2.96 & 2.60 & 1.42 & 3.12 & 3.00 \\
\hline Ethanol & 1.60 & $<1.00$ & 3.61 & 2.96 & 2.72 \\
\hline Acetate & 10.2 & 28.2 & 7.17 & 16.8 & 16.2 \\
\hline Lactate & 50.7 & 110.3 & 61.9 & 68.2 & 75.5 \\
\hline \multicolumn{6}{|c|}{ Composition $(\mathrm{g} / \mathrm{kg} \mathrm{DM})^{3}$} \\
\hline DM (wet weight) & 490 & 339 & 371 & 361 & 352 \\
\hline Organic matter & 894 & 884 & 906 & 877 & 891 \\
\hline NDF & 436 & 368 & 411 & 438 & 447 \\
\hline ADF & 384 & 333 & 403 & 364 & 367 \\
\hline Total CP & 196 & 196 & 139 & 196 & 198 \\
\hline Total phenols ${ }^{4}$ & 12.6 & 6.74 & 23.1 & 13.5 & 13.0 \\
\hline $\mathrm{CT}$ (total) & n.a. & n.a. & 136 & 34.6 & 22.5 \\
\hline Soluble CT & n.a. & n.a. & 37.0 & 22.3 & 7.8 \\
\hline Protein-bound CT & n.a. & n.a. & 78.7 & 7.1 & 11.2 \\
\hline Fibre-bound CT & n.a. & n.a. & 20.3 & 5.2 & 3.5 \\
\hline
\end{tabular}

$\mathrm{LU}=$ lucerne; $\mathrm{RC}=$ red clover; $\mathrm{SF}=$ sainfoin; $\mathrm{BTB}=$ birdsfoot trefoil, cv. Bull; $\mathrm{BTP}=$ birdsfoot trefoil, cv. Polom; $\mathrm{DM}=$ dry matter; $\mathrm{NH}_{3}=$ ammonia; $\mathrm{CT}=$ condensed tannins; n.a. $=$ not analysed.

${ }^{1}$ Analysed in the 1.5 I silos.

${ }^{2}$ Analysed in the 0.5 I silos.

${ }^{3}$ Analysed in the 30 I silos.

${ }^{4}$ Expressed as gallic acid equivalent per $\mathrm{kg}$ of DM. 
propanediol, butanediol and butanol) were below the analytical detection limits in all silages (data not shown). The OM content was almost equal across silages. Fibre contents were lowest in the RC silage, but the order in the other silage types differed between NDF (increasing from SF, LU, BTB, BTP) and ADF (increasing from BTB, BTP, LU, SF).

The CP content was by far the lowest in the SF silage (lower, on average, by $28 \%$ compared with the other treatments) followed by the RC, LU, BTP and BTB silages. The highest content of total phenolic compounds was found in the SF silage and the lowest in the RC silage, with intermediate levels in the LU, BTP and BTB silages. Among the CT-containing plants, the total CT were lowest in the BTP silage, followed by the BTB silage. The total CT content in the SF silage, was on average, almost five times higher than in the two BT cultivars. Most of the CT in the SF and BTP silages were bound to protein (58\% and $50 \%$ for SF and BTP, respectively). In the BTB silage, most of the CT were soluble (65\%).

The proportion of protein fraction $A$ in the fresh, wilted and ensiled legumes was lowest $(P<0.05)$ in SF. When compared with LU, the proportion of fraction A was lower $(P<0.05)$ in wilted and ensiled RC and ensiled BTB (Table 2). The proportion of the $B_{1}$ fraction in the fresh legumes was lowest $(P<0.05)$ for the SF samples. In the silages, it was lowest for the LU samples, followed by the BTB, RC, BTB and SF samples. Generally, the proportion of the $B_{2}$ fraction showed the greatest decline during the ensiling process and was lowest $(P<0.05)$ for the LU, BTB and BTP samples and highest in the SF samples, whereas the RC samples took an intermediate position in the fresh and ensiled samples. The proportion of the $B_{3}$ fraction was consistently lowest $(P<0.05)$ in the $L U$ samples and highest in the RC samples, whereas the SF, BTP and BTB samples took intermediate positions during the complete ensiling process. The proportion of the $C$ fraction was highest $(P<0.05)$ in the SF samples during the complete ensiling process.

\section{Differences in the effects on ruminal fermentation among the single legume silages}

No difference was noted among the single legume silages in terms of incubation fluid $\mathrm{pH}$ or total gas and $\mathrm{CH}_{4}$ production, or with ciliate protozoa counts (Table 3 ). The concentration of total VFA in the incubation fluid was highest $(P<0.05)$ for the RC samples and lowest for the SF samples; the other legumes (LU, BTB and BTP) took intermediate positions. The proportion of acetate was highest $(P<0.05)$ for the SF samples, intermediate for the LU samples and low for the samples of the three other legumes. The proportion of propionate was highest $(P<0.05)$ in the RC samples, lowest in the LU samples and intermediate in the three CT-containing legumes. The proportions of both $n$-butyrate and iso-valerate were lower $(P<0.05)$ in the SF samples compared with the other legumes. The proportion of iso-butyrate was highest $(P<0.05)$ in the LU and BTB samples, followed by the BTP, RC and SF samples. The $n$-valerate proportion was again highest in the LU samples, but lowest in the SF samples $(P<0.05)$, with the other samples falling between. The $\mathrm{NH}_{3}$
Table 2 Protein fractions of the fresh, wilted and ensiled legumes $(\mathrm{n}=3)$

\begin{tabular}{|c|c|c|c|c|c|c|c|}
\hline \multirow[b]{2}{*}{ Items } & \multicolumn{5}{|c|}{ Legumes } & \multirow[b]{2}{*}{ SEM } & \multirow[b]{2}{*}{$P$-value } \\
\hline & LU & $\mathrm{RC}$ & SF & BTB & BTP & & \\
\hline \multicolumn{8}{|c|}{ Fresh material } \\
\hline $\begin{array}{l}\text { Total CP } \\
\text { (g/kg DM) }\end{array}$ & $196^{\mathrm{a}}$ & $182^{\mathrm{a}}$ & $127^{b}$ & $187^{\mathrm{a}}$ & $188^{\mathrm{a}}$ & 40.9 & *** \\
\hline \multicolumn{8}{|c|}{ Protein fractions $(\mathrm{g} / \mathrm{kg} \text { of total } \mathrm{CP})^{1}$} \\
\hline A & $190^{\mathrm{a}}$ & $157^{\mathrm{ab}}$ & $128^{b}$ & $175^{a b}$ & $182^{\mathrm{a}}$ & 10.6 & * \\
\hline $\mathrm{B}_{1}$ & $221^{\mathrm{a}}$ & $185^{\mathrm{ab}}$ & $56^{c}$ & $159^{a b}$ & $135^{\mathrm{b}}$ & 15.6 & $* * *$ \\
\hline $\mathrm{B}_{2}$ & $519^{b}$ & $550^{\mathrm{b}}$ & $696^{\mathrm{a}}$ & $571^{b}$ & $585^{\mathrm{b}}$ & 16.6 & $* * *$ \\
\hline $\mathrm{B}_{3}$ & $29^{b}$ & $63^{\mathrm{a}}$ & $51^{\mathrm{ab}}$ & $49^{a b}$ & $58^{\mathrm{a}}$ & 5.9 & * \\
\hline $\mathrm{C}$ & $41^{b}$ & $44^{\mathrm{b}}$ & $69^{a}$ & $46^{\mathrm{b}}$ & $41^{\mathrm{b}}$ & 4.9 & * \\
\hline \multicolumn{8}{|c|}{ Wilted material } \\
\hline $\begin{array}{l}\text { Total CP } \\
\text { (g/kg DM) }\end{array}$ & $178^{\mathrm{a}}$ & $178^{\mathrm{a}}$ & $130^{b}$ & $179^{a}$ & $183^{a}$ & 29.4 & *** \\
\hline \multicolumn{8}{|c|}{ Protein fractions ( $\mathrm{g} / \mathrm{kg}$ of total CP) } \\
\hline A & $306^{\mathrm{a}}$ & $223^{\mathrm{bc}}$ & $184^{c}$ & $236^{\mathrm{abc}}$ & $274^{\mathrm{ab}}$ & 17.5 & ** \\
\hline $\mathrm{B}_{1}$ & $57^{x y}$ & $61^{x y}$ & $35^{y}$ & $90^{\mathrm{x}}$ & $69^{x y}$ & 11.4 & $t$ \\
\hline $\mathrm{B}_{2}$ & $510^{b}$ & $467^{c}$ & $563^{a}$ & $472^{c}$ & $472^{c}$ & 7.6 & $* * *$ \\
\hline $\mathrm{B}_{3}$ & $71^{\mathrm{c}}$ & $195^{\mathrm{a}}$ & $116^{b c}$ & $132^{b}$ & $133^{b}$ & 11.5 & $* * *$ \\
\hline $\mathrm{C}$ & $56^{\mathrm{b}}$ & $53^{b}$ & $102^{\mathrm{a}}$ & $70^{a b}$ & $53^{b}$ & 8.8 & * \\
\hline \multicolumn{8}{|l|}{ Silage $^{2}$} \\
\hline $\begin{array}{l}\text { Total CP } \\
\text { (g/kg DM) }\end{array}$ & $183^{\mathrm{a}}$ & $183^{\mathrm{a}}$ & $133^{b}$ & $187^{\mathrm{a}}$ & $185^{\mathrm{a}}$ & 38.2 & $* * *$ \\
\hline \multicolumn{8}{|c|}{ Protein fractions ( $\mathrm{g} / \mathrm{kg}$ of total $\mathrm{CP}$ ) } \\
\hline A & $589^{\mathrm{a}}$ & $394^{c}$ & $331^{d}$ & $536^{\mathrm{b}}$ & $546^{\mathrm{ab}}$ & 9.9 & $* * *$ \\
\hline $\mathrm{B}_{1}$ & 17 & 20 & 30 & 18 & 29 & 5.7 & Ns \\
\hline $\mathrm{B}_{2}$ & $292^{c}$ & $351^{\mathrm{b}}$ & $390^{\mathrm{a}}$ & $308^{c}$ & $291^{c}$ & 6.5 & $* * *$ \\
\hline $\mathrm{B}_{3}$ & $44^{c}$ & $174^{\mathrm{a}}$ & $161^{a}$ & $80^{b}$ & $80^{b}$ & 7.1 & $* * *$ \\
\hline$C$ & $59^{x y}$ & $60^{x y}$ & $89^{x}$ & $58^{x y}$ & $54^{y}$ & 8.2 & $\dagger$ \\
\hline
\end{tabular}

$\mathrm{LU}=$ lucerne; $\mathrm{RC}=$ red clover; SF = sainfoin; BTB = birdsfoot trefoil, cv. Bull; $\mathrm{BTP}=$ birdsfoot trefoil, $\mathrm{cv}$. Polom; DM = dry matter.

${ }_{\mathrm{a}, \mathrm{b}, \mathrm{c}, \mathrm{d}}$ Means within a row with different superscripts differ $(P<0.05)$.

${ }^{x, y}$ Means within a row with different superscripts tend to differ $(P<0.10)$.

${ }^{1}$ Protein fractions: $A=$ non-protein $N ; B_{1}=$ true soluble protein; $B_{2}=$ neutral detergent soluble protein; $B_{3}=$ protein insoluble in neutral detergent but soluble in acid detergent; $C=$ acid detergent insoluble protein.

${ }^{2}$ Analysed in the 1.5 I silos.

$+P<0.10, \quad{ }^{*} P<0.05, \quad{ }^{* *} P<0.01, \quad{ }^{* *} P<0.001, \quad N s=$ non-significant $(P>0.05)$

concentration of the incubation fluid was highest for the LU samples and lowest for the SF samples $(P<0.05)$. The three clover legumes took intermediate positions. The calculated content of $\mathrm{UCP}$ in the DM was lower $(P<0.05)$ in the SF samples when compared with the other legumes. However, the ratio of $\mathrm{UCP}$ to total $\mathrm{CP}$ was greatest $(P<0.05)$ for the SF samples when compared with the other legumes.

Effect of mixtures of non-condensed tannins-containing and condensed tannins-containing legume silages compared with the single legume silages

The mixtures of LU (Table 4) and RC (Table 5) with SF, BTB and BTP did not show differences in total gas and $\mathrm{CH}_{4}$ production or in $\mathrm{pH}$, total VFA concentration and ciliate protozoa counts in the incubation fluid. The LU-SF mixture, when compared with LU-BTB and LU-BTP mixtures, had a 
Table 3 Ruminal fermentation characteristics and utilisable CP at the duodenum when incubating silages from one legume only

\begin{tabular}{|c|c|c|c|c|c|c|c|}
\hline \multirow[b]{2}{*}{ Items } & \multicolumn{5}{|c|}{ Treatments } & \multirow[b]{2}{*}{ SEM } & \multirow[b]{2}{*}{$P$-value } \\
\hline & LU & $\mathrm{RC}$ & SF & BTB & BTP & & \\
\hline pH & 7.57 & 7.46 & 7.58 & 7.43 & 7.60 & 0.143 & Ns \\
\hline Total gas (ml/200 mg DM per $24 \mathrm{~h}$ ) & 42.4 & 43.7 & 38.4 & 40.9 & 39.4 & 6.22 & Ns \\
\hline \multicolumn{8}{|l|}{$\mathrm{CH}_{4}$} \\
\hline $\mathrm{ml} / 200 \mathrm{mg}$ DM per $24 \mathrm{~h}$ & 4.68 & 5.32 & 5.25 & 4.94 & 5.30 & 0.826 & Ns \\
\hline $\mathrm{ml} / \mathrm{l}$ total gas & 108 & 119 & 135 & 123 & 131 & 20.2 & Ns \\
\hline $\mathrm{ml} / \mathrm{mmol}$ total VFA & 66.8 & 73.8 & 81.1 & 75.7 & 78.3 & 13.56 & Ns \\
\hline Total protozoa $\left(\times 10^{4} / \mathrm{ml}\right)$ & 1.41 & 1.86 & 1.52 & 1.67 & 2.02 & 0.388 & Ns \\
\hline Entodiniomorphs $\left(\times 10^{4} / \mathrm{ml}\right)$ & 1.25 & 1.60 & 1.33 & 1.46 & 1.79 & 0.424 & Ns \\
\hline Holotrichs $\left(\times 10^{3} / \mathrm{ml}\right)$ & 0.81 & 2.22 & 1.41 & 1.30 & 2.22 & 1.539 & Ns \\
\hline VFA (mmol/l) & $70.5^{\mathrm{ab}}$ & $71.7^{\mathrm{a}}$ & $64.9^{c}$ & $68.1^{\mathrm{b}}$ & $68.1^{b}$ & 2.26 & ** \\
\hline Acetate (molar \%) & $67.9^{b}$ & $67.4^{c}$ & $69.4^{\mathrm{a}}$ & $67.3^{c}$ & $67.4^{c}$ & 0.43 & $* * *$ \\
\hline Propionate (molar \%) & $17.8^{c}$ & $18.9^{\mathrm{a}}$ & $18.5^{b}$ & $18.5^{\mathrm{b}}$ & $18.7^{\mathrm{ab}}$ & 0.22 & $* * *$ \\
\hline$n$-Butyrate (molar \%) & $9.59^{a}$ & $9.48^{\mathrm{a}}$ & $8.69^{b}$ & $9.69^{a}$ & $9.42^{\mathrm{a}}$ & 0.414 & $* * *$ \\
\hline Iso-butyrate (molar \%) & $1.14^{\mathrm{a}}$ & $1.02^{b}$ & $0.86^{c}$ & $1.14^{\mathrm{a}}$ & $1.11^{\mathrm{ab}}$ & 0.085 & $* * *$ \\
\hline$n$-Valerate (molar \%) & $1.56^{\mathrm{a}}$ & $1.32^{\mathrm{C}}$ & $1.09^{d}$ & $1.48^{\mathrm{b}}$ & $1.44^{\mathrm{b}}$ & 0.033 & $* * *$ \\
\hline Iso-valerate (molar \%) & $1.88^{\mathrm{a}}$ & $1.70^{\mathrm{a}}$ & $1.43^{b}$ & $1.87^{\mathrm{a}}$ & $1.81^{\mathrm{a}}$ & 0.184 & $* * *$ \\
\hline $\mathrm{NH}_{3}(\mathrm{mmol} / \mathrm{l})$ & $18.2^{\mathrm{a}}$ & $16.2^{b}$ & $13.0^{c}$ & $16.6^{\mathrm{b}}$ & $16.9^{\mathrm{ab}}$ & 0.96 & $* * *$ \\
\hline uCP (g/kg DM) & $193^{a}$ & $196^{\mathrm{a}}$ & $140^{\mathrm{b}}$ & $194^{\mathrm{a}}$ & $195^{\mathrm{a}}$ & 4.3 & $* * *$ \\
\hline $\mathrm{uCP}$ : total CP ratio & $0.986^{\mathrm{b}}$ & $0.994^{b}$ & $1.013^{\mathrm{a}}$ & $0.990^{\mathrm{b}}$ & $0.990^{\mathrm{b}}$ & 0.0099 & $* * *$ \\
\hline
\end{tabular}

$\mathrm{LU}=$ lucerne; $\mathrm{RC}=$ red clover; SF = sainfoin; BTB = birdsfoot trefoil, cv. Bull; BTP = birdsfoot trefoil, cv. Polom; DM = dry matter; $\mathrm{CH}_{4}=$ methane; VFA = volatile fatty acids; $\mathrm{NH}_{3}=$ ammonia; $\mathrm{uCP}=$ utilisable $\mathrm{CP}$ at the duodenum.

a,b,c,d Means within a row with different superscripts differ $(P<0.05)$.

${ }^{* *} P<0.01,{ }^{* *} P<0.001$, Ns $=$ non-significant $(P>0.05)$.

higher proportion of acetate and lower proportions of iso-butyrate, $n$-valerate and iso-valerate, as well as $\mathrm{NH}_{3}$ concentration, in the incubation fluid $(P<0.05)$. The calculated content of UCP in the DM was lower $(P<0.05)$ for the LU-SF mixture compared with the LU-BTB and LU-BTP mixtures, but the ratio of $\mathrm{UCP}$ to total $\mathrm{CP}$ was higher $(P<0.05)$ for the LU-SF compared with the LU-BTP mixture (not significant compared with the LU-BTB mixture). The same effects were observed when comparing mixtures of SF, BTB or BTP and RC, except that the proportions of isobutyrate, iso-valerate and $\mathrm{NH}_{3}$ concentration in the incubation fluid were only numerically lower with the RC-SF mixture, when compared with the RC-BTB and RC-BTP mixtures.

Generally, the differences between single silages and the mixtures containing BT silages were much less pronounced than those seen with SF silage mixtures. Furthermore, most of the effects of mixing single silages were additive, and only a few were synergistic or antagonistic compared with the single legumes. In brief, the LU-SF mixture showed higher $(P<0.05)$ counts for Holotrich protozoa compared with single LU but not to SF. When compared with LU but not to $B T B, L U-B T B$ mixture had incubation fluid with a lower $(P<0.05) \mathrm{pH}$, whereas the counts of total protozoa and of the entodiniomorphid protozoa were higher $(P<0.05)$. The RC-SF mixture resulted in a lower $(P<0.05) \mathrm{pH}$ of the incubation fluid and a higher $(P<0.05)$ total gas production compared with single SF but not with RC. Comparisons of RC-BTB with single BTB showed a higher $(P<0.05)$ concentration of total VFA in the incubation fluid and comparison of RC-BTP with single BTP showed a lower $(P<0.05)$ $\mathrm{pH}$ in the incubation fluid. In these traits, no difference occurred when compared with single RC.

\section{Discussion}

Fermentation quality of the silages

The production of silages with high nutritional value, especially from legumes with high buffering capacity, still appears to be challenging without the use of additives (Muck, 1988). When no fast decline in $\mathrm{pH}$ is realised, proteolysis of the plant protein is not suppressed, resulting in high proportions of $\mathrm{N}$ as soluble compounds (Muck, 1988). In the present study, the quality of the silages produced in laboratory silos was generally good in all treatments, as evident by the fast decline and the low terminal pH. Consequently, only traces of undesired organic acids, like butyrate, were produced. The DM loss was also negligible, indicating a good compacting and sealing.

\section{Differences among legumes in their effect on ruminal fermentation and methanogenesis}

Although the effect of CT on ruminal carbohydrate degradation is regarded as a secondary anti-nutritional effect compared with that on protein degradation, the formation of complexes of CT with cellulose, hemicellulose and pectin (McSweeney et al., 2001) can reduce ruminal fermentation which, in turn, decreases the ruminal VFA and total gas 
Table 4 Effect of mixture $(1: 1)$ of lucerne and the condensed tannins-containing legumes itself and compared with the single legumes on ruminal fermentation characteristics and supply with utilisable $\mathrm{CP}$ at the duodenum

\begin{tabular}{|c|c|c|c|c|c|c|c|c|c|c|c|}
\hline \multirow[b]{3}{*}{ Items } & \multicolumn{11}{|c|}{ Treatments } \\
\hline & \multicolumn{3}{|c|}{ LU-SF } & \multicolumn{3}{|c|}{ LU-BTB } & \multicolumn{3}{|c|}{ LU-BTP } & \multirow[b]{2}{*}{ SEM } & \multirow[b]{2}{*}{$P$-value } \\
\hline & Diff. to $\mathrm{LU}^{1}$ & Observations & Diff. to SF & Diff. to LU & Observations & Diff. to BTB & Diff. to LU & Observations & Diff. to BTP & & \\
\hline $\mathrm{pH}$ & -0.17 & 7.40 & -0.18 & $-0.17^{y}$ & 7.40 & -0.03 & -0.07 & 7.50 & -0.10 & 0.192 & Ns \\
\hline Total gas (ml/200 mg DM per $24 \mathrm{~h}$ ) & +0.6 & 43.0 & +4.6 & -0.8 & 41.6 & +0.7 & -1.3 & 41.1 & +1.7 & 2.43 & Ns \\
\hline \multicolumn{12}{|l|}{$\mathrm{CH}_{4}$} \\
\hline $\mathrm{ml} / 200 \mathrm{mg}$ DM per $24 \mathrm{~h}$ & \pm 0.00 & 4.68 & -0.57 & +0.51 & 5.19 & +0.25 & +0.20 & 4.88 & -0.42 & 0.442 & Ns \\
\hline $\mathrm{ml} / \mathrm{l}$ total gas & +2 & 110 & $-25^{2}$ & +13 & 121 & -2 & +12 & 120 & -11 & 11.0 & Ns \\
\hline $\mathrm{ml} / \mathrm{mmol}$ total VFA & +2.2 & 69.0 & -12.1 & +7.4 & 74.2 & -1.5 & +1.3 & 68.1 & -10.2 & 7.25 & Ns \\
\hline Total protozoa $\left(\times 10^{4} / \mathrm{ml}\right)$ & +0.35 & 1.76 & +0.24 & $+0.64^{Y}$ & 2.05 & +0.38 & +0.40 & 1.81 & -0.21 & 0.270 & Ns \\
\hline Entodiniomorphs $\left(\times 10^{4} / \mathrm{ml}\right)$ & +0.15 & 1.40 & +0.07 & $+0.53^{Y}$ & 1.78 & +0.32 & +0.37 & 1.62 & -0.17 & 0.277 & Ns \\
\hline Holotrichs $\left(\times 10^{3} / \mathrm{ml}\right)$ & $+2.10^{Y}$ & 2.91 & +1.50 & +1.66 & 2.47 & +1.17 & +1.07 & 1.88 & -0.34 & 1.131 & Ns \\
\hline VFA (mmol/l) & -1.4 & 69.1 & $+4.2^{\mathrm{Z}}$ & +0.7 & 71.2 & +3.1 & -1.1 & 69.4 & +1.3 & 1.94 & Ns \\
\hline Acetate (molar \%) & $+0.6^{Y}$ & $68.5^{\mathrm{a}}$ & $-0.9^{z}$ & -0.4 & $67.5^{b}$ & +0.2 & -0.2 & $67.7^{\mathrm{b}}$ & +0.3 & 0.29 & $* * *$ \\
\hline Propionate (molar \%) & $+0.3^{Y}$ & 18.1 & $-0.4^{\mathrm{z}}$ & $+0.4^{Y}$ & 18.2 & -0.3 & $+0.4^{Y}$ & 18.2 & $-0.5^{z}$ & 0.16 & Ns \\
\hline$n$-Butyrate (molar \%) & -0.24 & 9.35 & $+0.66^{\mathrm{Z}}$ & -0.03 & 9.56 & -0.13 & +0.03 & 9.62 & +0.20 & 0.278 & Ns \\
\hline Iso-butyrate (molar \%) & $-0.16^{Y}$ & $0.98^{\mathrm{b}}$ & $+0.12^{\mathrm{z}}$ & +0.01 & $1.15^{\mathrm{a}}$ & +0.01 & -0.02 & $1.12^{\mathrm{a}}$ & +0.01 & 0.058 & $* *$ \\
\hline$n$-Valerate (molar \%) & $-0.22^{Y}$ & $1.34^{\mathrm{b}}$ & $+0.25^{z}$ & -0.02 & $1.54^{\mathrm{a}}$ & +0.06 & -0.04 & $1.52^{\mathrm{a}}$ & $+0.08^{z}$ & 0.030 & $* * *$ \\
\hline Iso-valerate (molar \%) & $-0.27^{Y}$ & $1.61^{\mathrm{b}}$ & +0.18 & -0.03 & $1.85^{\mathrm{a}}$ & -0.02 & -0.04 & $1.84^{\mathrm{a}}$ & +0.03 & 0.131 & * \\
\hline $\mathrm{NH}_{3}(\mathrm{mmol} / \mathrm{l})$ & $-3.6^{Y}$ & $14.6^{\mathrm{b}}$ & $+1.6^{\mathrm{z}}$ & -1.2 & $17.0^{\mathrm{a}}$ & +0.4 & -0.7 & $17.5^{\mathrm{a}}$ & +0.6 & 0.86 & $* * *$ \\
\hline uCP (g/kg DM) & $-25^{\mathrm{Y}}$ & $168^{\mathrm{b}}$ & $+28^{\mathrm{Z}}$ & +1 & $194^{\mathrm{a}}$ & \pm 0 & +1 & $194^{\mathrm{a}}$ & -1 & 1.8 & $* * *$ \\
\hline uCP : total CP ratio & $+0.011^{Y}$ & $0.997^{\mathrm{a}}$ & $-0.016^{\mathrm{z}}$ & \pm 0.000 & $0.986^{\mathrm{ab}}$ & -0.004 & -0.001 & $0.985^{b}$ & -0.005 & 0.0072 & * \\
\hline
\end{tabular}

LU = lucerne; SF = sainfoin; BTB = birdsfoot trefoil, cv. Bull; BTP = birdsfoot trefoil, cv. Polom; LU-SF = mixture of LU and SF (1:1); LU-BTB = mixture of LU and BTB (1:1); LU-BTP = mixture of LU and BTP (1:1); DM = dry matter; $\mathrm{CH}_{4}=$ methane; VFA = volatile fatty acids; $\mathrm{NH}_{3}=$ ammonia; $\mathrm{UCP}=$ utilisable $\mathrm{CP}$ at the duodenum.

a,b Means within a row with different superscripts differ $(P<0.05)$.

Y, $\mathrm{Z}$ Means of the mixture are different $(P<0.05)$ from means found with either LU or SF, BTB and BTP, respectively (data from Table 3).

Difference between the value observed in the mixtures and the respective single legumes (Table 3 ).

${ }^{*} P<0.05,{ }^{* *} P<0.01,{ }^{* *} P<0.001$, Ns $=$ non-significant $(P>0.05)$. 
Table 5 Effect of mixture $(1: 1)$ of red clover $(R C)$ and the condensed tannins-containing legumes itself and compared with the single legumes on ruminal fermentation characteristics and supply with utilisable $C P$ at the duodenum

\begin{tabular}{|c|c|c|c|c|c|c|c|c|c|c|c|}
\hline \multirow[b]{3}{*}{ Items } & \multicolumn{11}{|c|}{ Treatments } \\
\hline & \multicolumn{3}{|c|}{$\mathrm{RC}-\mathrm{SF}$} & \multicolumn{3}{|c|}{$\mathrm{RC}-\mathrm{BTB}$} & \multicolumn{3}{|c|}{ RC-BTP } & \multirow[b]{2}{*}{ SEM } & \multirow[b]{2}{*}{$P$-value } \\
\hline & Diff. to $\mathrm{RC}^{1}$ & Observations & Diff. to SF & Diff. to $\mathrm{RC}$ & Observations & Diff. to BTB & Diff. to $\mathrm{RC}$ & Observation & Diff. to BTP & & \\
\hline $\mathrm{pH}$ & -0.17 & 7.29 & $-0.29^{\mathrm{Z}}$ & -0.16 & 7.30 & -0.13 & -0.04 & 7.42 & $-0.18^{\mathrm{Z}}$ & 0.200 & Ns \\
\hline Total gas (ml/200 mg DM per $24 \mathrm{~h}$ ) & +0.5 & 44.2 & $+5.8^{\mathrm{Z}}$ & -0.6 & 43.1 & +2.2 & -2.5 & 41.2 & +1.8 & 1.49 & Ns \\
\hline \multicolumn{12}{|l|}{$\mathrm{CH}_{4}$} \\
\hline $\mathrm{ml} / 200 \mathrm{mg}$ DM per $24 \mathrm{~h}$ & -0.30 & 5.02 & -0.23 & -0.38 & 4.94 & \pm 0.00 & -0.38 & 4.94 & -0.36 & 0.408 & Ns \\
\hline $\mathrm{ml} / \mathrm{l}$ total gas & -5 & 114 & -21 & -3 & 116 & -7 & -1 & 118 & -13 & 9.0 & Ns \\
\hline $\mathrm{ml} / \mathrm{mmol}$ total VFA & -1.7 & 72.1 & -9.0 & -5.1 & 68.7 & -7.0 & -4.2 & 69.6 & -8.7 & 7.42 & Ns \\
\hline Total protozoa $\left(\times 10^{4} / \mathrm{ml}\right)$ & -0.27 & 1.59 & +0.07 & +0.12 & 1.98 & +0.31 & -0.03 & 1.83 & -0.19 & 0.340 & Ns \\
\hline Entodiniomorphs $\left(\times 10^{4} / \mathrm{ml}\right)$ & -0.16 & 1.44 & +0.11 & +0.22 & 1.82 & +0.36 & +0.03 & 1.63 & -0.16 & 0.364 & Ns \\
\hline Holotrichs $\left(\times 10^{3} / \mathrm{ml}\right)$ & -1.11 & 1.11 & -0.30 & -1.41 & 0.81 & -0.49 & -0.63 & 1.59 & -0.63 & 0.996 & Ns \\
\hline VFA (mmol/l) & -1.9 & 69.8 & $+4.9^{\mathrm{Z}}$ & +0.6 & 72.3 & $+4.2^{\mathrm{Z}}$ & -0.3 & 71.4 & +3.3 & 2.36 & Ns \\
\hline Acetate (molar \%) & $+0.7^{Y}$ & $68.1^{\mathrm{a}}$ & $-1.3^{\mathrm{Z}}$ & \pm 0.0 & $67.4^{b}$ & +0.1 & -0.1 & $67.3^{\mathrm{b}}$ & -0.1 & 0.34 & $* *$ \\
\hline Propionate (molar \%) & -0.2 & 18.7 & +0.2 & \pm 0.0 & 18.9 & $+0.4^{\mathrm{Z}}$ & -0.1 & 18.8 & +0.1 & 0.14 & Ns \\
\hline$n$-Butyrate (molar \%) & -0.11 & 9.37 & $+0.68^{\mathrm{Z}}$ & +0.03 & 9.51 & -0.18 & +0.14 & 9.62 & +0.20 & 0.280 & Ns \\
\hline Iso-butyrate (molar \%) & -0.05 & 0.97 & $+0.11^{\mathrm{z}}$ & +0.02 & 1.04 & -0.10 & +0.05 & 1.07 & -0.04 & 0.070 & Ns \\
\hline$n$-Valerate (molar \%) & $-0.09^{Y}$ & $1.23^{\mathrm{b}}$ & $+0.14^{\mathrm{Z}}$ & $+0.06^{Y}$ & $1.38^{\mathrm{a}}$ & $-0.10^{\mathrm{z}}$ & $+0.08^{Y}$ & $1.40^{\mathrm{a}}$ & $-0.04^{Z}$ & 0.030 & $* * *$ \\
\hline Iso-valerate (molar \%) & -0.09 & 1.61 & +0.18 & +0.04 & 1.74 & -0.13 & +0.08 & 1.78 & -0.03 & 0.138 & Ns \\
\hline $\mathrm{NH}_{3}(\mathrm{mmol} / \mathrm{l})$ & -0.9 & 15.3 & $+2.3^{z}$ & +1.0 & 17.2 & +0.6 & +1.4 & 17.6 & +0.7 & 1.42 & Ns \\
\hline uCP (g/kg DM) & $-29^{Y}$ & $167^{\mathrm{b}}$ & $+27^{Z}$ & -3 & $193^{a}$ & -1 & -1 & $195^{\mathrm{a}}$ & \pm 0 & 2.1 & $* * *$ \\
\hline uCP : total CP ratio & +0.004 & $0.998^{\mathrm{a}}$ & $-0.015^{\mathrm{Z}}$ & -0.011 & $0.983^{b}$ & -0.007 & -0.008 & $0.986^{\mathrm{ab}}$ & -0.004 & 0.0070 & * \\
\hline
\end{tabular}

$\mathrm{uCP}$ : total CP ratio

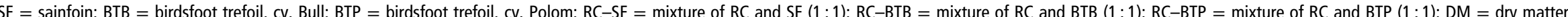
$\mathrm{CH}_{4}=$ methane; VFA = volatile fatty acids; $\mathrm{NH}_{3}=$ ammonia; $\mathrm{UCP}=$ utilisable $\mathrm{CP}$ at the duodenum.

a,b

Y,Z Means of the mixture are different $(P<0.05)$ from means found with either LU or SF, BTB and BTP, respectively (data from Table 3 ).

${ }^{1}$ Difference between the value observed in the mixtures and the respective single legumes (Table 3 ).

${ }^{*} P<0.05,{ }^{* *} P<0.01,{ }^{* * *} P<0.001, \mathrm{Ns}=$ non-significant $(P>0.05)$. 
production (Azuhnwi et al., 2011). Consistent with this, the VFA concentration was lower in all CT-containing legumes when compared with the non-CT-containing legumes in the present study, and this was most pronounced with SF, which had the highest CT content. Although not statistically significant, the total gas amounts indicate the same.

In cases where the $\mathrm{CT}$ decreased the extent of fibre degradation, this could result in a lower $\mathrm{CH}_{4}$ production, but a direct anti-methanogenic effect of $\mathrm{CT}$ is also possible (Patra and Saxena, 2011). However, although VFA production was lower for the SF samples when compared with the LU and RC samples, the absolute and relative $\mathrm{CH}_{4}$ production was not reduced and the change in the VFA profile towards acetate in the SF samples was due to a relative decrease in butyrate. Chung et al. (2013) observed no influence of SF on $\mathrm{CH}_{4}$ production, and Williams et al. (2010) reported no effect for BT. This lack of effect could be due to the CT content, the CT structure, or both, because the content and structure can vary considerably, not only among plant species (MuellerHarvey, 2006) but also within species, as well as with respect to harvest time and cultivation site (Azuhnwi et al., 2013).

Another reason for the lack of an effect on $\mathrm{CH}_{4}$ in the SF and BT samples, compared with the LU samples, might be the saponin content of the LU samples. Saponins have the potential to form complexes with sterols in the cell walls of protozoa (Cheeke, 2000) and thereby reduce the $\mathrm{CH}_{4}$ production by reducing the number of protozoa or by other mechanisms independent of the presence of protozoa (Hess et al., 2003). However, as there was no clear difference in methanogenesis between the LU and RC silages, the specific properties of the LU samples were obviously too weak to have any effect on methanogenesis.

\section{Differences among legumes in protein degradation during ensiling and ruminal fermentation}

Forage diets that are characterised by easily degradable protein, as is the case with many silages, promote the formation of $\mathrm{NH}_{3}$ in the rumen. $\mathrm{NH}_{3}$ cannot be efficiently used by the ruminal microbes in case of excessive dietary $\mathrm{CP}$ or deficient fermentable OM supply or both. The surplus $\mathrm{NH}_{3}$ will be absorbed by the ruminant and will need to undergo detoxification into urea in the liver and be excreted in the urine. Excessive $\mathrm{NH}_{3}$ absorption therefore could result in metabolic stress in the animal due to its effects on liver health and the costs in terms of energy expenditure (Lobley et al., 1995). This is also an undesirable outcome in environmental terms, as the urea in urine is easily transformed into $\mathrm{NH}_{3}$, nitrate and nitrous oxides during manure storage and distribution on the field (Dijkstra et al., 2013). Wilting of plants before ensiling can be effective in reducing the amount of protein fraction $A$ in favour of the $B_{2}$ and $B_{3}$ protein fractions. This has the effect of counteracting the excessive production of $\mathrm{NH}_{3}$ in the rumen and increasing the content of $\mathrm{UCP}$, as ruminal undegradable protein is mainly composed of the $B_{3}$ and $C$ fractions (Edmunds et al., 2014).

In the present study, the silages prepared from SF seemed to decelerate proteolysis during the ensiling process.
Although the non-protein $\mathrm{N}$ fraction $\mathrm{A}$ was already lower in fresh SF material, the proportion of fraction A was markedly lower in the SF silage than was observed in the other legume silages. In addition, the protein from fractions $B_{1}$ and $B_{2}$ shifted to the $B_{3}$ and $C$ protein fractions during the ensiling of SF and resulted in the highest ratio of UCP to total CP when compared with the other silages. Copani et al. (2014) similarly found a lower content of soluble N in SF silage compared with timothy grass silage, and Scharenberg et al. (2007) observed a higher ratio of UCP to total CP in SF silage compared with BT and chicory silage. $\mathrm{CT}$ form stable complexes with proteins (Mueller-Harvey, 2006) and thereby decelerate or even prevent ruminal degradation of these proteins, as microbes are unable to cleave these complexes (McSweeney et al., 2001). The low $\mathrm{NH}_{3}$ concentration and the reduced proportion of isoVFA in the incubation fluid of SF silage compared with LU indicates an interaction of proteins with $\mathrm{CT}$ in the present study. However, the low $\mathrm{NH}_{3}$ concentration observed in the SF samples could result from its concomitantly low CP content and proportion of fraction A or its high CT content compared with the other legume silages. Alternatively, it could be a result of a later developmental stage of the plant at harvest or a combination of all these possibilities.

Apart from $\mathrm{CT}$, other bioactive substances are known to reduce proteolysis; for example, the polyphenol oxidase is an enzyme that catalyses the formation of o-quinones (Lee et al., 2008). RC contains polyphenol oxidase as shown by Copani et al. (2014). These authors also reported a lower amount of soluble $\mathrm{N}$ in RC silage ( $33 \%$ of total $\mathrm{N}$ ) compared with timothy grass silage ( $55 \%$ of total $\mathrm{N})$. The non-protein $\mathrm{N}$ fraction $A$ in the $R C$ silage in the present study was lower than that found in the $\mathrm{LU}$ silage. The $\mathrm{NH}_{3}$ concentration in the incubation fluid from RC was also lower than that found in the fluid from $L U$, indicating an effect of o-quinones on ruminal protein degradation or silage fermentation or both, resulting in a lower proportion of protein fraction $\mathrm{A}$ that in turn reduced the $\mathrm{NH}_{3}$ concentration.

The small effect of CT on proteolysis in the BTB and BTP silages compared with SF silage, and the especially low effect of the BTP silages on $\mathrm{NH}_{3}$ concentration in the incubation fluid, were most likely the result of too low CT contents, partially caused by the high weed proportions in the swards. However, this effect could partly be a result of different CT structures. CT consist of varying proportions of prodelphinidins and procyanidins, which differ in the size of their polymers. These differences can influence their reactivity to form complexes with other polymers (Patra and Saxena, 2011). Therefore, differences between SF and BT would be expected, as the main $\mathrm{CT}$ in SF are prodelphinidins, whereas they are procyanidins in BT (compiled by Mueller-Harvey, 2006). Furthermore, the two BT cultivars differed in their CT fractions. A larger part of the CT in BTB was soluble, whereas about half of the CT in BTP were bound to proteins; this difference might explain the contrasting effectiveness of the two cultivars.

Complexes with $\mathrm{CT}$ are assumed to be released below $\mathrm{pH} 4$ (Mangan, 1988), as it is the case in the abomasum. Ideally, 
therefore, the amount of undegradable protein and hence the amount of UCP (Waghorn, 2008) should be increased so that it contributes to the metabolisable protein supply. The ratio of $U C P$ to total CP was indeed higher for SF than for all other silages tested in the present study, which suggests that this legume silage might improve the dietary protein utilisation and animal performance in diets that are limited in uCP but not in energy.

\section{Type of response to mixtures in ruminal fermentation compared with effects of single legume silages}

Mixing of forage plants may help to improve the forage quality by combining the positive effects of different plants. Ideally, the bioactive compounds present in some plants would act additively or synergistically when mixed and would improve the fermentation characteristics when compared with each single plant (Jayanegara et al., 2013). In the present study, no completely synergistic effects (i.e. significantly different from both respective single legumes) were observed. Nevertheless, some incompletely synergistic effects (significantly different from one single legume and numerically different in the same direction from the other single legume) were observed with mixtures of a CT-containing legume with $\mathrm{RC}$ or LU. These incompletely synergistic effects were manifested as a greater gas production (RC-SF) and a greater VFA concentration (RC-BTB), whereas the mixtures of LU-SF and LU-BTB showed greater numbers of protozoa. The lack of fully synergistic effects is most likely due to the low $\mathrm{CT}$ content of the mixtures, which is consistent with other literature reporting no synergistic effects of mixtures of SF and BT with LU (Williams et al., 2010; Chung et al., 2013). Nevertheless, synergistic effects may not be the only benefits, as additive effects (where the value of the mixture is in the middle, between the values of the two respective single legumes) could also have a positive impact on forage quality. For instance, the mixtures of SF with LU and RC, when compared with single $\mathrm{LU}$ and $\mathrm{RC}$, reduced protein degradation to $\mathrm{NH}_{3}$ and enhanced the content of $\mathrm{UCP}$.

\section{Conclusion}

The present findings showed that, by wilting the material before ensiling, it is possible to produce silages of the same quality as with common non-CT-containing legumes, even though no additives were applied in any of the silages. This confirms the first hypothesis. SF (and RC) silages resulted in a more favourable protein fraction profile because ensiling these plants proportionately decreased non-protein $\mathrm{N}$ and increased $B_{3}$ protein when compared with LU silage. This could have resulted from the effect of bioactive compounds (CT and polyphenol oxidase). In the case of SF, this translated into a higher proportionate supply of $\mathrm{UCP}$ at the duodenum. Compared with SF, the BT cultivars, which contained much less $C T$, had little effect on protein-related traits. This shows that with SF, the second hypothesis was correct, but that it cannot be generalised to all CT-containing legumes and to low CT levels. Some positive effects were obtained by mixing
CT-containing and non-CT-containing legumes in terms of lowering the ruminal $\mathrm{NH}_{3}$ concentration and increasing the supply of $\mathrm{UCP}$, which could motivate farmers to integrate CT-containing legumes into ruminant diets. These findings confirm the third hypothesis. Mixing CT-containing and nonCT-containing legumes already during the ensiling process might reduce $\mathrm{N}$ losses even more and improve forage quality further. This has to be clarified by further research.

\section{Acknowledgements}

This study was supported by the EU Marie Curie Initial Training Network ('LegumePlus'; PITN-GA-2011-289377). The authors are grateful to Peter Stirnemann of the lab team at ETH Zurich for his assistance.

\section{References}

Association of Official Analytic Chemists (AOAC) 1995. Official methods for analysis, vol. 2, 16th edition. AOAC, Arlington, VA, USA.

Azuhnwi BN, Boller B, Dohme-Meier F, Hess HD, Kreuzer M, Stringanod E and Mueller-Harvey I 2013. Exploring variation in proanthocyanidin composition and content of sainfoin (Onobrychis viciifolia). Journal of the Science of Food and Agriculture 93, 2102-2109.

Azuhnwi BN, Boller B, Martens M, Dohme-Meier F, Ampuero S, Günter S, Kreuzer $M$ and Hess HD 2011. Morphology, tannin concentration and forage value of 15 Swiss accessions of sainfoin (Onobrychis viciifolia Scop.) as influenced by harvest time and cultivation site. Grass and Forage Science 66, 474-487.

Charmley E 2001. Towards improved silage quality - a review. Canadian Journal of Animal Science 81, 157-168.

Cheeke P 2000. Actual and potential applications of Yucca schidigera and Quillaja saponaria saponins in human and animal nutrition. Journal of Animal Science 77, 1-10.

Chung YH, Mc Geough E, Acharya S, McAllister T, McGinn S, Harstad 0 and Beauchemin K 2013. Enteric methane emission, diet digestibility, and nitrogen excretion from beef heifers fed sainfoin or alfalfa. Journal of Animal Science 91, 4861-4874.

Copani G, Ginane C, Le Morvan A and Niderkorn V 2014. Bioactive forage legumes as a strategy to improve silage quality and minimise nitrogenous losses. Animal Production Science 54, 1826-1829.

Dijkstra J, Oenema 0, Van Groenigen J, Spek J, Van Vuuren A and Bannink A 2013. Diet effects on urine composition of cattle and $\mathrm{N}_{2} \mathrm{O}$ emissions. Animal 7, 292-302.

Edmunds B, Spiekers $H$, Südekum KH, Nussbaum H, Schwarz F and Bennett R 2014. Effect of extent and rate of wilting on nitrogen components of grass silage. Grass and Forage Science 69, 140-152.

Hess H-D, Kreuzer M, Díaz TE, Lascano CE, Carulla JE, Soliva CR and Machmüller A 2003. Saponin rich tropical fruits affect fermentation and methanogenesis in faunated and defaunated rumen fluid. Animal Feed Science and Technology 109, 79-94.

Jayanegara A, Marquardt S, Wina E, Kreuzer M and Leiber $F$ 2013. In vitro indications for favourable non-additive effects on ruminal methane mitigation between high-phenolic and high-quality forages. British Journal of Nutrition 109, 615-622.

Jones GA, McAllister TA, Muir AD and Cheng KJ 1994. Effects of sainfoin (Onobrychis viciifolia Scop.) condensed tannins on growth and proteolysis by four strains of ruminal bacteria. Applied and Environmental Microbiology 60, 1374-1378.

Lee MRF, Scott MB, Tweed JKS, Minchin FR and Davies DR 2008. Effects of polyphenol oxidase on lipolysis and proteolysis of red clover silage with and without a silage inoculant (Lactobacillus plantarum L54). Animal Feed Science and Technology 144, 125-136.

Licitra G, Hernandez TM and Van Soest PJ 1996. Standardization of procedures for nitrogen fractionation of ruminant feeds. Animal Feed Science and Technology 57, 347-358. 


\section{Grosse Brinkhaus, Wyss, Arrigo, Girard, Bee, Zeitz, Kreuzer and Dohme-Meier}

Lobley GE, Connell A, Lomax MA, Brown DS, Milne E, Calder AG and Farningham DAH 1995. Hepatic detoxification of ammonia in the ovine liver: possible consequences for amino acid catabolism. British Journal of Nutrition 73, 667-685.

Lüscher A, Mueller-Harvey I, Soussana JF, Rees RM and Peyraud JL 2014. Potential of legume-based grassland-livestock systems in Europe: a review. Grass and Forage Science 69, 206-228.

Mangan JL 1988. Nutritional effects of tannins in animal feeds. Nutrition Research Reviews 1, 209-231.

McSweeney CS, Palmer B, McNeill DM and Krause DO 2001. Microbial interactions with tannins: nutritional consequences for ruminants. Animal Feed Science and Technology 91, 83-93.

Menke $\mathrm{KH}$ and Steingass $\mathrm{H}$ 1988. Estimation of the energetic feed value obtained from chemical analysis and in vitro gas production using rumen fluid. Animal Research and Development 28, 7-55.

Muck R 1988. Factors influencing silage quality and their implications for management. Journal of Dairy Science 71, 2992-3002.

Mueller-Harvey I 2006. Unravelling the conundrum of tannins in animal nutrition and health. Journal of the Science of Food and Agriculture 86, 2010-2037.

Patra AK and Saxena J 2011. Exploitation of dietary tannins to improve rumen metabolism and ruminant nutrition. Journal of the Science of Food and Agriculture 91, 24-37.

R Core Team 2014. R: a language and environment for statistical computing. R Foundation for Statistical Computing, Vienna, Austria.

Salminen J and Karonen M 2011. Chemical ecology of tannins and other phenolics: we need a change in approach. Functional Ecology 25, 325-338.

Scharenberg A, Arrigo Y, Gutzwiller A, Soliva CR, Wyss U, Kreuzer M and Dohme F 2007. Palatability in sheep and in vitro nutritional value of dried and ensiled sainfoin (Onobrychis viciifolia) birdsfoot trefoil
(Lotus corniculatus), and chicory (Cichorium intybus). Archives of Animal Nutrition 61, 481-496.

Sheldrick R, Thomson D and Newman G 1995. Legumes for milk and meat, 2nd edition. Chalcombe Publications, Shedfield, UK.

Soliva CR and Hess HD 2007. Measuring methane emission of ruminants by in vitro and in vivo techniques. In Measuring methane production from ruminants (ed.. HPS Makkar and PE Vercoe), pp. 15-31. Springer, Dordrecht, The Netherlands.

Steingass H and Südekum KH 2013. Proteinbewertung beim Wiederkäuer Grundlagen, analytische Entwicklungen und Perspektiven. Übersichten zur Tierernährung 41, 51-73.

Terrill TH, Rowan AM, Douglas GB and Barry TN 1992. Determination of extractable and bound condensed tannin concentrations in forage plants, protein concentrate meals and cereal grains. Journal of the Science of Food and Agriculture 58, 321-329.

Waghorn G 2008. Beneficial and detrimental effects of dietary condensed tannins for sustainable sheep and goat production - progress and challenges. Animal Feed Science and Technology 147, 116-139.

Wang Y, Berg B, Barbieri L, Veira D and McAllister T 2006. Comparison of alfalfa and mixed alfalfa-sainfoin pastures for grazing cattle: effects on incidence of bloat, ruminal fermentation, and feed intake. Canadian Journal of Animal Science 86, 383-392.

Weissbach F and Kuhla S 1995. Substance losses in determining the dry matter content of silage and green fodder: arising errors and possibilities of correction. Übersichten zur Tierernährung 23, 189-214.

Wilkinson JM and Toivonen MI 2003. World silage: a survey of forage conservation around the world. Chalcombe Publications, Lincoln, UK.

Williams C, Eun J-S, Dschaak C, MacAdam JW, Min B and Young A 2010. Case study: in vitro ruminal fermentation characteristics of birdsfoot trefoil (Lotus corniculatus L.) hay in continuous cultures. The Professional Animal Scientist 26, 570-576. 